been found. A few sills near Vælddal at the south coast of Traill $\varnothing$ consisting of ankaramite or pyroxene porphyritic dolerite are possibly related to the younger Kap Simpson intrusion.

\title{
References
}

Backlund, H. G. \& Malmqvist, D. 1932: Zur Geologie und Petrographie der nordostgrönländischen Basaltformation. Teil I. Die basische Reihe. Meddr Grønland 87,5, 61 pp.

Bütler, H. 1954: Die stratigraphische Gliederung der mitteldevonischen Serien im Gebiete von Kap Franklin am Kejser Franz Joseph Fjord in Zentral-Ostgrönland. Meddr Grønland 116,7, 126 pp.

Graeter, P. 1957: Die sauren devonischen Eruptivgesteine des Kap Franklingebiets am Kejser Franz Josephs Fjord in Zentral-Ostgrönland. Meddr Grønland 155,3, 102 pp.

Koch, L. \& Haller, J. 1971: Geological map of East Greenland $72^{\circ}-76^{\circ}$ N. Lat. 1:250 000. Meddr Grønland 183, $26 \mathrm{pp}$.

Maync, W. 1940: Stratigraphie des Küstengebietes von Ostgrönland zwischen $73-75^{\circ} \mathrm{N}$. Lat. (Östliche Gauss Halvø, Hold-with-Hope, östliche Clavering $\varnothing$, Wollaston Forland, Kuhn $\varnothing$, Sabine $\varnothing$ und Lille Pendulum Ø). Meddr Grønland 114,5, 34 pp.

Maync, W. 1942: Stratigraphie und Faziesverhältnisse der oberpermischen Ablagerungen Ostgrönlands (olim "Oberkarbon-Unterperm") zwischen Wollaston Forland und dem Kejser Franz Josephs Fjord. Meddr Grønland 115,2, $128 \mathrm{pp}$.

Maync, W. 1949: The Cretaceous beds between Kuhn Island and Cape Franklin (Gauss Peninsula), Northern East Greenland. Meddr Grønland 133,3, $291 \mathrm{pp}$.

Noe-Nygaard, A. 1976: Tertiary igneous rocks between Shannon and Scoresby Sund, East Greenland. In Escher, A. \& Watt, W. S. (edit.) Geology of Greenland, 386-402. Copenhagen: Geol. Surv. Greenland.

Upton, B. G. J. \& Emeleus, C. H. 1977: The Tertiary geology of Hold with Hope, northern East Greenland. Rapp. Grønlands geol. Unders. 85, 115-121.

Vischer, A. 1943: Die postdevonische Tektonik von Ostgrönland zwischen $74^{\circ}$ und $75^{\circ} \mathrm{N}$. Br. Kuhn Ø, Wollaston Forland, Clavering $\varnothing$ und angrenzende Gebiete. Meddr Grønland 133,1,194 pp.

Geologisk Museum, $\emptyset$ ster Voldgade 5-7, 1350 Copenhagen $K$.

\section{Project EASTMAR: a new aeromagnetic survey of the continental shelf of eastern Greenland}

\section{Leif Thorning}

GGU has been working for some years with plans for investigation of the continental shelf of eastern Greenland. The first detailed suggestion for a systematic, regional aeromagnetic survey of most of the shelf area was worked out by the writer in 1975, and this project has been accepted by the Energy Commission of the Danish Ministry of Commerce as an energy research project to be carried out by GGU in the period from September 1977 to September 
1980. The budget amounts to approximately 8.5 mill. kr. over three years, the funds being provided through the Energy Commission. Detailed plans of the project are given in Thorning (1977); this note briefly presents the project as it will be carried out by the Geophysics Section of GGU. The scientific staff involved will be H. C. Larsen, employed on a three-year contract financed by the Energy Commission, and the writer as project manager. For some specific purposes consultants will be used.

\section{Aim of the project}

The general aim of EASTMAR is, mainly through aeromagnetics, but also exploiting other sources of data, to map, study and understand the lithologies and structures of the continental shelf, with special emphasis on the delineation and analyses of sedimentary basins. Evidence for some basins is already known; others may still remain to be demonstrated. The project will make available for the first time a considerable amount of systematic data from a very large part of the shelf, thus allowing for a reasonable evaluation of the oil and gas potential of the continental margin. In addition new information relating to the geology and geophysics of a large part of coastal Greenland will be forthcoming. The difficult, often hazardous conditions for marine surveys on the seas off the east coast of Greenland are well known. The practical knowledge accumulated in the course of EASTMAR will hopefully improve the odds for good results of later marine surveys.

\section{Nature of the project}

Project EASTMAR divides naturally into four phases.

The first which started in September 1977, consists of several related activities. Apart from the intensive study of existing literature and results from the region, a comprehensive analysis of unpublished seismic, bathymetric and other data is in progress. Of particular importance here is the compilation and interpretation of the regional aeromagnetic surveys carried out by the U.S. Naval Oceanographic Office and U.S. Naval Research Laboratory. These agencies have kindly allowed GGU full use of their aeromagnetic data from the East, North-East and North Greenland shelf and neighbouring areas. The information hereby obtained will be invaluable in the assessment and planning of our own aeromagnetic surveys to be carried out in phase three.

The second phase of EASTMAR, the negotiation of contracts with commercial companies for the aeromagnetic survey work, will begin by summer 1978. GGU's own instrumentation is inadequate for the nature of the envisaged work and the survey thus will be put on offer to private commercial companies. The final details of the work will be agreed in cooperation with the selected company, taking into account the scientific objectives, the practicalities of logistics, and the ability and performance of the available aircraft and instrument configuration.

Phase three of EASTMAR, the actual running of the aeromagnetic surveys, has preliminarily been planned for the first half of 1979 . For navigation a combination of an inertial system and Doppler radar almost certainly will have to be used and it may be advantageous to carry out the airborne operations while the water is still ice-covered. This will add to the accuracy of most navigational systems using Doppler radar. Depending on developing prices, it is planned to fly 40.000 to 50000 line kilometres over various parts of the shelf so that 
gaps in the existing aeromagnetic coverage will be closed and more detailed information will be obtained from areas of proven interest. The attempt will be to cover in sufficient detail as large a part of the shelf as is economically and logistically possible.

During the fourth phase, starting at the end of the airborne operations in 1979, a final interpretation of the old and new data will be performed. The major results probably will be presented as magnetic contour maps and interpretational maps but as yet the scale and exact coverage of these maps is not decided. Intermediate results during the project will be reported to Danish authorities in a number of scientific and technical reports, and to the scientific community in the usual manner through scientific journals and at meetings. All results will be gathered in a major publication to be expected by the end of the project.

\section{Discussion}

It is important to note that the completion of this project in 1980 does in no way signal the opening of general exploration for oil and gas on the eastern Greenland continental shelf. Decisions on such matters remain to be taken by the relevant authorities. GGU intends to continue working in the region using other methods, e.g. marine seismic surveys and 1980 is thought to be a suitable time for the start of such activity. With the increased knowledge of the shelf gained through project EASTMAR the critical targets for future marine surveys can be carefully pin-pointed.

\section{Reference}

Thorning, L. 1977: Aeromagnetiske undersøgelser af den østgrønlandske kontinentale margin. I: Planer for projektets udførelse. Grønlands geol. Unders. Int. unpubl. rep. 23 pp.

\section{$\mathrm{Rb} / \mathrm{Sr}$ age of the Kap Washington Group, Peary Land, North Greenland, and its geotectonic-implication}

\section{Ole Larsen, Peter R. Dawes and Norman J. Soper}

The Kap Washington Group is a bedded suite of rhyolitic lavas and tuffs that forms the northernmost rock province of Greenland (Dawes \& Soper, 1973). The volcanic group borders on the north the Palaeozoic North Greenland fold belt from which it is separated by the southerly-dipping Kap Cannon thrust (fig. 38). K/Ar whole-rock age determinations of $34.9 \pm 5.3 \mathrm{~m} . y$. and $32.3 \pm 3.2$. m.y. on somewhat mylonitised lava samples were earlier regarded as giving an approximate minimum age of volcanic consolidation and a maximum age of the Kap Cannon thrusting (Dawes \& Soper, 1971).

This note reports on $\mathrm{Rb} / \mathrm{Sr}$ isotopic work that dates the Kap Washington Group, the five 